Sains Malaysiana 49(9)(2020): 2311-2322

http://dx.doi.org/10.17576/jsm-2020-4909-28

\title{
Treatment of Palm Oil Mill Effluent by Poly(L-Lactic Acid)-Poly(Ethylene Glycol)/ Silica Membrane
}

\author{
(Rawatan Efluen Kilang Sawit menggunakan Membran Poli(L-Asid Laktik)-Poli(Etilena Glikol)/Silika)
}

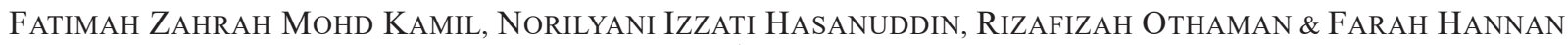 \\ ANUAR*
}

\begin{abstract}
Biodegradable membrane technology has received an increasing interest in many fields of applications exclusively to preserve the earth. A renewable polymer such as poly(L-lactic acid) (PLLA) often being introduced with reinforcement material to improve the characteristics of membranes itself. Herein, this study highlights the development of membrane from poly(L-lactic acid)-poly(ethylene glycol) (PLLA-PEG) copolymer with silica (SiO $)_{2}$ in the treatment of palm oil mill effluent (POME) wastewater. We hypothesized that the incorporation of $\mathrm{SiO}_{2}$ as a nanofiller promoted PLLA-PEG/ $\mathrm{SiO}_{2}$ membrane to have a porous and higher number of pores on the membrane surface. Therefore, the effect of silica amount added in the PLLA-PEG copolymer membrane was also investigated and examined by using Fourier transform infrared spectroscopy (FTIR), scanning electron microscopy (SEM) and energy dispersive X-ray spectroscopy (EDX). Based on FTIR analysis, the presence of the urethane (-NHCOO-) functional group indicated the formation of PLLAPEG copolymer and SEM micrographs showed porous surface on the membranes with increasing pores size in a favor of $\mathrm{SiO}_{2}$ amount added. Also, the surface wettability of membranes was evaluated through water contact angle which render hydrophilic characteristics. These membranes were subsequently applied for POME filtration where the test resulted in significant discolouration of POME. Furthermore, the high percentage removal efficiency of biochemical oxygen demand (BOD), chemical oxygen demand (COD) and total suspended solid (TSS) up to 99.5\% empowers the treated POME wastewater to be within the range set by the Malaysian Department of the Environment.
\end{abstract}

Keywords: Copolymer; membrane; poly(ethylene glycol); poly(lactic acid); POME

\section{ABSTRAK}

Pada masa kini, teknologi membran terbiodegradasi semakin mendapat perhatian dalam pelbagai bidang aplikasi khususnya untuk menjaga kesejahteraan bumi. Polimer yang berasaskan sumber keterbaharuan seperti poli(asid laktik) selalunya ditambah baik dengan bahan penguat bagi meningkatkan ciri membran tersebut. Oleh itu, kajian ini memfokuskan kepada perkembangan membran berasaskan kopolimer poli(L-asid laktik)-poli(etilena glikol) (PLLAPEG) dengan penambahan silika bagi rawatan air sisa buangan efluen minyak kelapa sawit. Kami menjangkakan bahawa penambahan silika sebagai pengisi di dalam membran PLLA-PEG/SiO 2 menjadikan permukaannya berliang dan mampu meningkatkan bilangan liang. Oleh itu, kesan penambaan berat silika ke dalam membran kopolimer PLLAPEG dikaji menggunakan FTIR, SEM dan EDX. Berdasarkan analisis FTIR, pembentukan kopolimer PLLA-PEG telah dibuktikan dengan kehadiran kumpulan berfungsi uretana (-NHCOO-) dan mikrograf SEM menunjukkan permukaan berliang yang terdapat pada membran selain terdapat peningkatan dari segi saiz liang selepas penambahan berat silika. Seterusnya, kebolehbasahan permukaan membran telah dinilai melalui analisis sudut sentuhan air kerana telah memperlihatkan ciri-ciri kehidrofilikan. Kesemua membran ini telah diaplikasikan bagi rawatan POME yang telah menunjukkan perubahan penyahwarnaan yang signifikan. Tambahan lagi, kadar peratusan penyingkiran yang tinggi bagi BOD, COD dan TSS sehingga 99.5\% telah membuatkan air sisa POME yang terawat berada dalam had pengeluaran yang telah dikeluarkan oleh Jabatan Alam Sekitar Malaysia.

Kata kunci: Kopolimer; membran; poli(etilena glikol); poli(L-asid laktik); POME

\section{INTRODUCTION}

Currently, Malaysia dominates global palm oil production by almost $40 \%$ and accounts for about $44 \%$ of exports across the world. Standing next to Indonesia, Malaysia is one of the biggest exporter and producer in the palm oil industry that plays a crucial role in meeting the growing global demand for its oils and fats sustainably. Despite being a significant sector behind the national economic growth, problems arise where 9.9 million tons of solids 
wastes and 20 million tons of palm oil mill effluent (POME) are generated every year. In response to these issues, tremendous efforts were done to curb the thick dark brownish colour effluent that generated from mills. This dark brown effluent or POME can destroy many aquatic plants whenever dumped into the nearby river and indirectly affect human health as the river has been one of the water resource for human (Ghani et al. 2018). Other than that, this hazardous liquid waste has an unpleasant odor and highly polluted with high biochemical and chemical oxygen demand (BOD \& COD).

Nevertheless, there are several common methods employed to treat POME mainly to decrease BOD and COD values of effluent such as biological treatment. This treatment uses a combination effect of aerobic, anaerobic, and facultative ponds. However, undeniable drawbacks are still present as there is no significant reduction in POME color even after the biological treatment. The color of POME was displayed to be dark brownish due to the degradation of lignocellulosic compounds which are lignin and tannin (Ali Amat et al. 2015). Therefore, the use of biodegradable membrane technology will be a great solution in providing green chemistry that could separate the residues and eventually changes the color of effluent. A green biodegradable polymer such as poly(L-lactic acid) (PLLA) is the most prominent polymer that widely used in various applications especially in packaging, flame retardant, biomedical field and membranes (Basu et al. 2018; El-Gendy et al. 2017; Liu et al. 2004; Nasrin et al. 2017). PLLA is a versatile polymer made from renewable agricultural raw materials such as corn and potatoes that makes them great in biocompatibility, processability, and biodegradability (Feng et al. 2016; Xian et al. 2018). PLLA interestingly has high stiffness and strength, thermoplastic, transparent, and recyclable (Gui et al. 2012). However, PLLA is a hydrophobic polymer with inherent brittleness and poor toughness (Nagarajan et al. 2016). In order for PLLA based materials to possess the hydrophilic character for water surface wettability, a hydrophilic polymer such as polyethylene glycol (PEG) needs to be introduced into the PLLA surface or membrane matrix.

PEG is water-soluble and an excellent plasticizer for PLLA to form a good miscible solution (Chen et al. 2005). Besides that, PEG can increase the porosity and thickness of a membrane (Saljoughi et al. 2010). In this research, we attempted to synthesis a potentially biodegradable membrane with a combination of PLLAPEG multiblock copolymer as the membrane matrix and silica as a pore-forming agent and filler. This multiblock copolymerization technique was chosen over polymer blending merely to improve the original physical-chemical properties of the material and provide good miscibility (Ruf et al. 2018). To date, there are significant numbers of literature on PLLA as the main material in membranes (Gaitán et al. 2018; Phaechamud et al. 2016; Wang et al. 2016). The study by Chieng et al. (2014) disclosed that even though PLA plasticized with PEG increased the flexibility of PLA, other properties such as thermal stability and mechanical strength still can be improved by the addition of reinforcement nanofiller. On the other hand, study on PLLA-PEG copolymer membrane with silica and its application in POME treatment has not yet been performed. The incorporation of silica during the PLLAPEG membrane fabrication is particularly interesting as it can behave as an adsorbent in the membrane as well as a pore template that increases the porosity of the membrane. The amount of silica is varied at different percentages which were $0,2,6$, and $10 \%$ and the resulting membranes were characterized to examine their physicalchemical properties and membrane performance.

\section{MATERIALS AND METHOD}

\section{MATERIALS}

PLLA was purchased from ESUN, China. PEG $\left(\mathrm{M}_{\mathrm{w}}=10000 \mathrm{~g} / \mathrm{mol}\right)$, tin(II) 2-ethylhexanoate ( $\mathrm{Sn}(\mathrm{oct})_{2}$, 95\%), 1,6-hexamethylene diisocyanate (HMDI, 98\%), dichloromethane (DCM), tetrahydrofuran (THF) and silica were purchased from Sigma-Aldrich (Malaysia) in analytical grade. All chemicals and reagents were used without further purification. Silica gel was sieved to the size of $45 \mu \mathrm{m}$ prior to use. For further performance application of membranes, the palm oil mill effluent (POME) wastewater was taken from Labu, Negeri Sembilan $\left(2^{\circ} 47.08 \mathrm{~N}\right.$ and $\left.102^{\circ} 30.25 \mathrm{E}\right)$ and collected from the final discharge pond.

\section{METHOD}

PLLA-PEG copolymer used as the membrane matrix was prepared using PLLA:PEG weight ratio of 7:3, before adding with a variable amount of silica as described in Table 1.

TABLE 1. Composition of copolymer PLLA-PEG/SiO $\mathrm{S}_{2}$ membranes

\begin{tabular}{cccc}
\hline Copolymer membranes & $\begin{array}{c}\text { Weight of } \\
\text { PLLA }\end{array}$ & $\begin{array}{c}\text { Weight of } \\
\text { PEG }\end{array}$ & $\begin{array}{c}\text { Weight of } \\
\text { silica }\end{array}$ \\
\hline $0 \%$ silica membranes & $7 \mathrm{~g}$ & $3 \mathrm{~g}$ & $0.0 \mathrm{~g}$ \\
$2 \%$ silica membranes & $7 \mathrm{~g}$ & $3 \mathrm{~g}$ & $0.2 \mathrm{~g}$ \\
$6 \%$ silica membranes & $7 \mathrm{~g}$ & $3 \mathrm{~g}$ & $0.6 \mathrm{~g}$ \\
$10 \%$ silica membranes & $7 \mathrm{~g}$ & $3 \mathrm{~g}$ & $1.0 \mathrm{~g}$ \\
\hline
\end{tabular}


PREPARATION OF PLLA-PEG/SILICA

PLLA (7 g) pellets were dissolved into $42 \mathrm{~mL}$ of DCM in a round bottom flask and covered with a greased flask stopper. The solution was stirred for $2 \mathrm{~h}$ to completely dissolve PLLA. In the meantime, silica was stirred in $42 \mathrm{~mL}$ of THF in a beaker. After $2 \mathrm{~h}, 3 \mathrm{~g}$ of PEG was added into the flask that contains PLLA solution, followed by $36 \mathrm{mg}$ of $\mathrm{Sn}(\mathrm{Oct})_{2}$ and $0.7 \mathrm{~g}$ of HMDI. The solution was stirred for another $2 \mathrm{~h}$ at $45^{\circ} \mathrm{C}$ allowing PLLA-PEG multiblock copolymer to form. Then, the silica/THF mixture was added into the flask containing the PLLA-PEG copolymer solution and stirred overnight at $45{ }^{\circ} \mathrm{C}$. This step was repeated several times with different percentages of silica as described in Table 1.

\section{FABRICATION OF PLLA-PEG/SILICA MEMBRANE}

The modified fabrication of membrane was carried out based on previous study in the phase immersion method. PLLA-PEG/silica solution was casted onto a glass plate with a thickness of $0.20 \mathrm{~mm}$ using a casting knife (Norfarhana 2014). After leaving for a few minutes at room temperature, the glass plate was immersed into distilled water in a basin. Then, an off-white solid membrane was formed and carefully peeled off. The samples were kept for the next characterization.

\section{PERFORMANCE TEST OF MEMBRANE}

Raw POME is a combination wastes coming from three principal sources, which are clarification wastewater $(60 \%)$, sterilizer condensate $(36 \%)$ and hydrocyclone wastewater (4\%). This waste is made of $95-96 \%$ water, $4-5 \%$ total solids which consist of $2-4 \%$ suspended solids as well as $0.6-0.7 \%$ oil and grease that had been discharged at $80-90{ }^{\circ} \mathrm{C}$ of temperature (Ang et al. 2018). Permeation tests for POME were done to study the flux of the membranes by using dead-end stirred cell model HP4750. The membrane was cut into a size of $50 \mathrm{~mm}$ in diameter and tested under nitrogen gas at constant pressure starting from 0.5 bar. Then, the reading was taken for $50 \mathrm{~min}$ in $5 \mathrm{~min}$ interval. For the quality test of POME, removal of BOD, COD and TSS as well as $\mathrm{pH}$ were analyzed according to methods published by American Public Health Association (APHA), American Water Works Association and Water Environment Federation. Each test was performed with different instruments and standard method which were HACH method 8000, HACH DR 3900 and ALPHA 2540 D. Table 2 displays the physicochemical parameter of POME with their respective standard discharge limit by the Malaysian Department of the Environment (DOE).

TABLE 2. Physicochemical parameter of POME by DOE standard

\begin{tabular}{lcc}
\hline \multicolumn{1}{r}{ Parameter } & POME taken in Labu & DOE standard \\
\hline $\mathrm{pH}$ & 8.39 & $5-9$ \\
$\mathrm{BOD}(\mathrm{mg} / \mathrm{L})$ & 12300 & 20 \\
$\mathrm{COD}(\mathrm{mg} / \mathrm{L})$ & 40820 & - \\
$\mathrm{TSS}(\mathrm{mg} / \mathrm{L})$ & 38693 & 400 \\
Oil and grease $(\mathrm{mg} / \mathrm{L})$ & 2000 & 50 \\
Total nitrogen & 750 & 150 \\
\hline
\end{tabular}

Source: Zainal et al. (2017)

\section{CHARACTERIZATION}

The presence of structural functional groups of PLLAPEG copolymer membranes was identified by using Fourier transform infrared spectroscopy (FTIR). FTIR spectra were recorded using Spectrum 400 Perkin Elmer GX Spectrometer over the range between 4000 and 650 $\mathrm{cm}^{-1}$. Membranes morphologies were investigated by using scanning electron microscopy (SEM) under the magnification at $10000 \times$ for membrane surface and
$1000 \times$ and $5000 \times$ for membrane cross-sectional imaging. The presence of elements in membranes was determined by using energy dispersive X-ray (EDX) analysis. Water contact angle analysis of membranes was characterized by the Drop Shape Analyzer model DO 4010 KRUSS using the sessile drop method. Deionized water $(4 \mu \mathrm{L})$ was dropped on the membranes and observed. A total of 5 spots for each membranes were tested and the average value was taken. 


\section{RESULTS AND DISCUSSION}

\section{PLLA AND PEG COPOLYMERIZATION}

The reaction between end groups of PLLA and PEG with HMDI resulted in a polyurethane-based PLLA-PEG copolymer. Urethane functional group that serves as a linkage between the homopolymers is produced by reacting two isocyanate groups (-NCO) from HMDI with the two hydroxyl groups (-OH) from PLLA or PEG in the presence of a catalyst. As in this case, the $-\mathrm{OH}$ group of PLLA and PEG served as a nucleophile and attacked an electron-deficient center $(\mathrm{N}=\mathrm{C}=\mathrm{O})$ of HMDI and when this reaction is repeated, a multiblock copolymer type is obtained. The reaction scheme of the synthesis of PLLAPEG polyurethane copolymers can be seen in Figure 1 that results in random copolymer backbone (Sidik et al. 2018).<smiles>CCOC(C)C(=O)OC</smiles><smiles>CCCOCC</smiles><smiles>O=C=NCN=C=O</smiles>

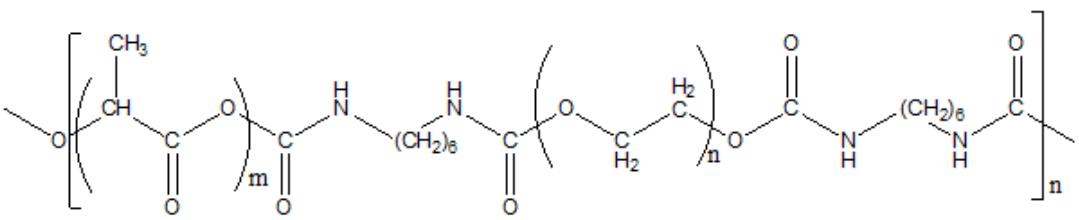

FIGURE 1. Reaction scheme between PLLA, HMDI and PEG to produce PLLA-PEG polyurethane copolymer

FTIR ANALYSIS

The successful formation of the copolymer can be validated by the data of FTIR spectra with the presence of the urethane (-NHCOO-) functional group. This functional group is significant to prove the formation of PLLA-PEG copolymer. Furthermore, FTIR analysis was carried out to evaluate the presence of silica after the membrane fabrication process. Table 3 shows the wavenumber of functional groups for pristine PLLA, pristine PEG, PLLA-PEG copolymer membrane, and PLLA-PEG/silica membrane. The FTIR absorption bands for pristine PLLA and PEG were obtained through the previous literatures reported (Nasrin et al. 2017; Zainuddin et al. 2018).

TABLE 3. FTIR absorption bands of pristine PLLA, pristine PEG and PLLA-PEG/silica membrane

\begin{tabular}{lccccccc}
\hline & $\begin{array}{c}\mathrm{C}-\mathrm{H} \\
\text { stretching }\end{array}$ & $\begin{array}{c}\mathrm{C}=\mathrm{O} \\
\text { stretching }\end{array}$ & $\begin{array}{c}\mathrm{O}=\mathrm{C}-\mathrm{N} \\
\text { stretching }\end{array}$ & $\begin{array}{c}\mathrm{C}-\mathrm{N} \\
\text { stretching }\end{array}$ & $\begin{array}{c}\mathrm{C}-\mathrm{O}-\mathrm{C} \\
\text { stretching }\end{array}$ & $\begin{array}{c}\text { Si-O } \\
\text { stretching }\end{array}$ & Si-O-Si \\
\hline PLLA & 2996,2946 & 1756 & - & - & - & - \\
PEG & 2914,2882 & - & - & - & 1105 & - \\
PLLA-PEG & 2997,2941 & 1755 & 1619 & 1210 & 1082 & - & 842 \\
PLLA-PEG/ & 2996,2945 & 1751 & 1621 & 1214 & 1182 & 960,1100 & 802 \\
$\mathrm{SiO}_{2}$ & & & & & & & \\
\hline
\end{tabular}


Based on FTIR spectra analysis in Figure 2, PLLA$\mathrm{PEG} / \mathrm{SiO}$ membrane exhibited almost similar peaks with PLLA-PEG copolymer membrane in their spectrum despite the added silica. These spectra showed that the urethane (-NHCOO-) functional group has positively well-formed in both membranes. C-H stretching with $\mathrm{sp}^{3}$ character was observed at $2997 \mathrm{~cm}^{-1}$ and $2945 \mathrm{~cm}^{-1}$ in each spectrum whereas a very intense and sharp peak at $1750-1756 \mathrm{~cm}^{-1}$ was represented by $\mathrm{C}=\mathrm{O}$ stretching of carboxylic acid functional group. This carbonyl group peak remains unchanged as in pristine PLLA during the reaction of PLLA and HMDI. It is because only the O-H group of the polymers reacted with -NCO from HMDI. Other than that, an obvious peak was seen at $960 \mathrm{~cm}^{-1}$ and around $1100 \mathrm{~cm}^{-1}$ corresponds to the Si-O group while peak at $842 \mathrm{~cm}^{-1}$ was attributed to symmetry stretching of Si-O-Si as detected in Figure 2 (Chen et al. 2010). However, the peak at $1100 \mathrm{~cm}^{-1}$ was not clearly visible as it is overlapped by C-O-C group present in matrix membrane. Furthermore, to verify the presence of -NHCOO- functional group, a new set of peak observed at the range of $1619-1621 \mathrm{~cm}^{-1}$ can be assigned to the urethane $\mathrm{C}=\mathrm{O}$ group and another new peak at the range of $1210-1263 \mathrm{~cm}^{-1}$ belongs to $\mathrm{C}-\mathrm{N}$ of urethane. The presence of these two peaks was necessary to prove that the urethane -NHCOO- bond was successfully formed in this copolymerization reaction.

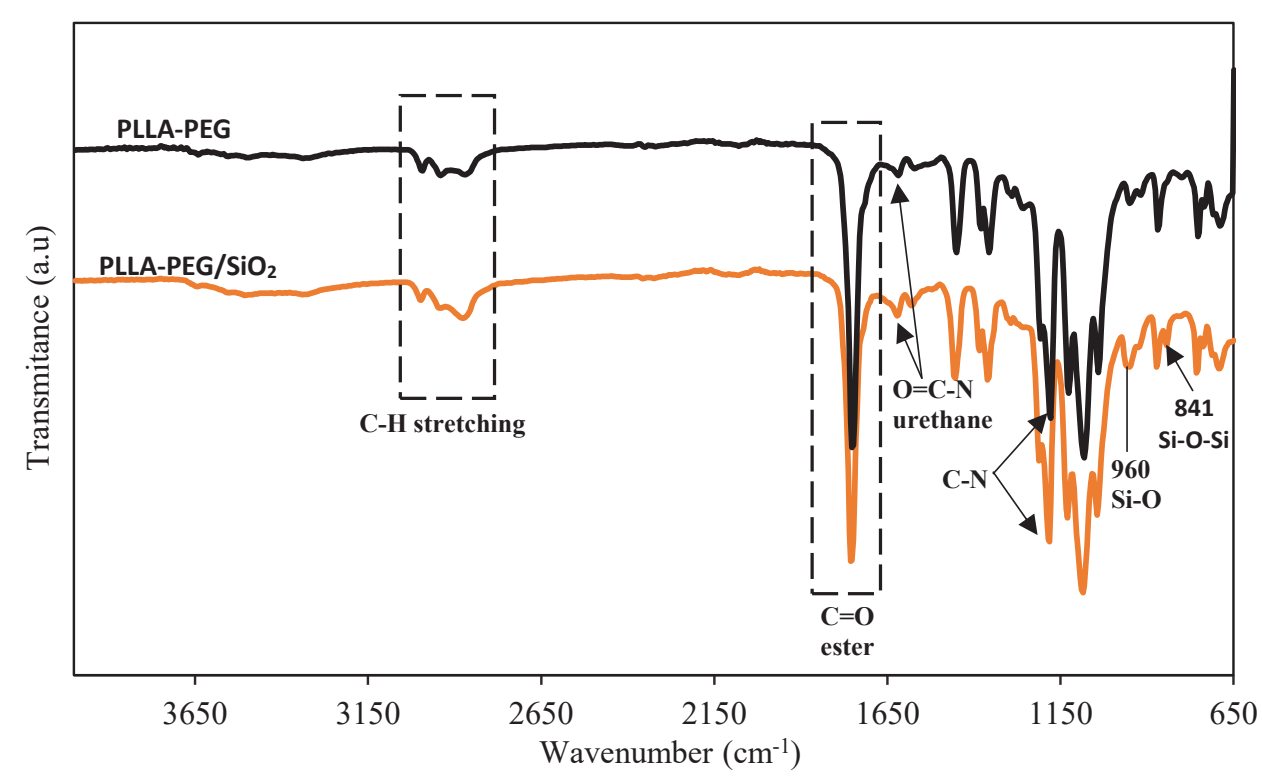

FIGURE 2. FTIR spectrum for PLLA-PEG copolymer membrane and a representative PLLA-PEG/SiO membrane

\section{MORPHOLOGY ANALYSIS}

Surface and cross-sectional imaging on the morphology of membranes were investigated by using SEM micrograph to compare the pore size and porosity of membranes. Figure 3 illustrates the SEM micrograph on membrane surface with a variation in the percentages of silica. PLLAPEG copolymer membrane fabricated without silica (Figure 3(a)) showed smooth surface with the presence of well-distributed pores. In comparison to Figure 3(a), PLLAPEG copolymer membranes with 2,6 , and $10 \%$ of silica (Figure 3(b)-3(c)) also displayed well distributed pores, but higher surface porosity and larger pores. After the inclusion of $2 \%$ of silica, the average pore size decreased from $1.89 \mu \mathrm{m}$ in $0 \%$ membrane to $0.97 \mu \mathrm{m}$. Then, further addition of silica at $6 \%$ increased the average pore size to $1.24 \mu \mathrm{m}$. This trend was similar with the literature reported by Feifel and Lisdat (2011) and Mahatmanti et al. (2018) where pore distribution was found increasing with the addition of silica. This phenomena could be related to the properties of silica and size exclusion effect. The hydrophilic nature of silica made them acted as a poreforming agent that attributed to the formation of more pores and larger pore sizes. 
However, Figure 3(d) presented a micrograph of $10 \%$ silica membrane with average pore size of 5.70 $\mu \mathrm{m}$ that is remarkably different from other membranes. Irregular and non-uniform large pores are observed and this can be due to the agglomeration of silica at relatively high concentration during copolymer-filler-solvent mixing.
Another factor that contributed to this was the leaching of silica from membrane film during phase inversion process in water, since silica is hydrophilic and the interaction between silica particles with membrane matrix is merely physical.
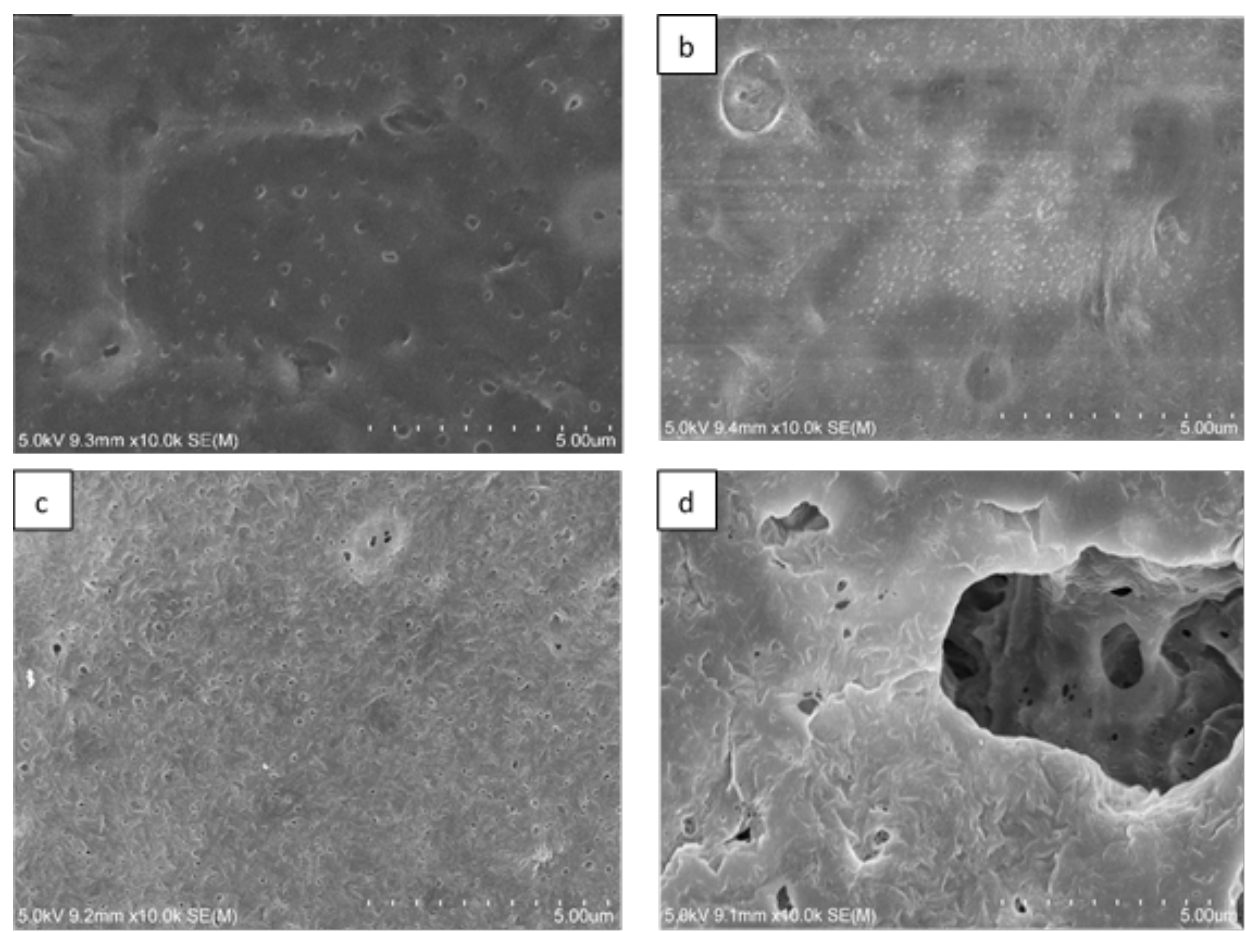

FIGURE 3. RSEM micrograph for membrane surfaces fabricated with (a) $0 \%$, (b) $2 \%$, (c) $6 \%$, and (d) $10 \%$ silica at 10000 magnification

Meanwhile, Figure 4 shows the cross-sectional imaging of the membranes at 1000 and 5000 magnification. Overall, SEM analysis of membranes fabricated with $0,2,6$, and $10 \%$ silica indicated high compatibility between PLLA and PEG segments of the PLLA-PEG copolymer and silica with no occurrence of phase separation. Their topographies were also similar to each other. The pore sizes for each membrane was measured and the average sizes for membrane with $0 \%$ of silica was found to be $2.16 \mu \mathrm{m}$ and $2 \%$ of silica was measured at the average of $1.56 \mu \mathrm{m}$. The average pore sizes of 6 and $10 \%$ membrane were found to be 1.62 and $2.80 \mu \mathrm{m}$, respectively. However, in Figure 4(h), an agglomerated silica has been observed inside the matrix membrane. This phenomenon occurred due to excess of the addition of silica into the PLLA-PEG copolymer membrane.

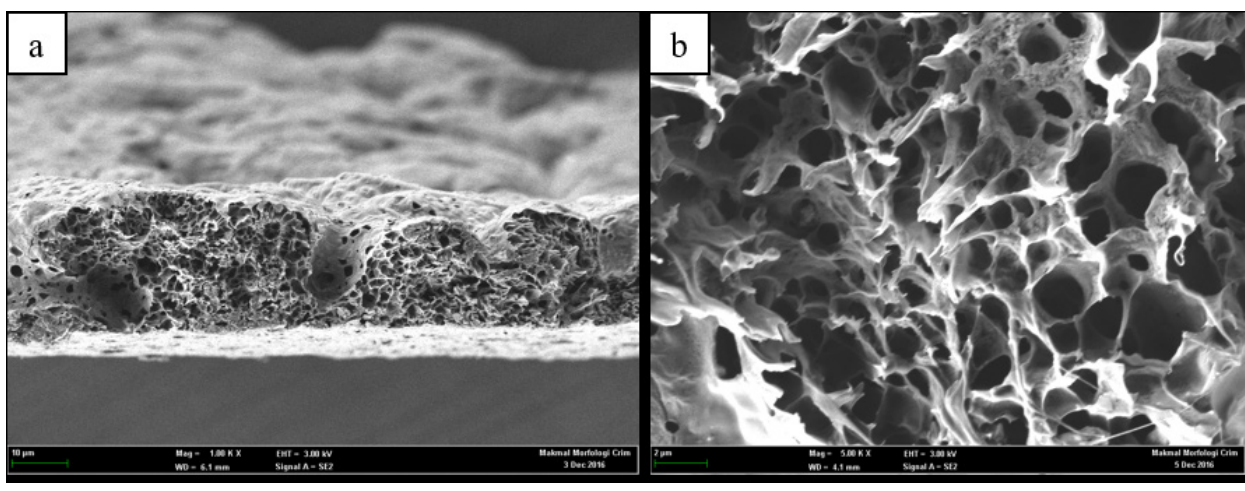



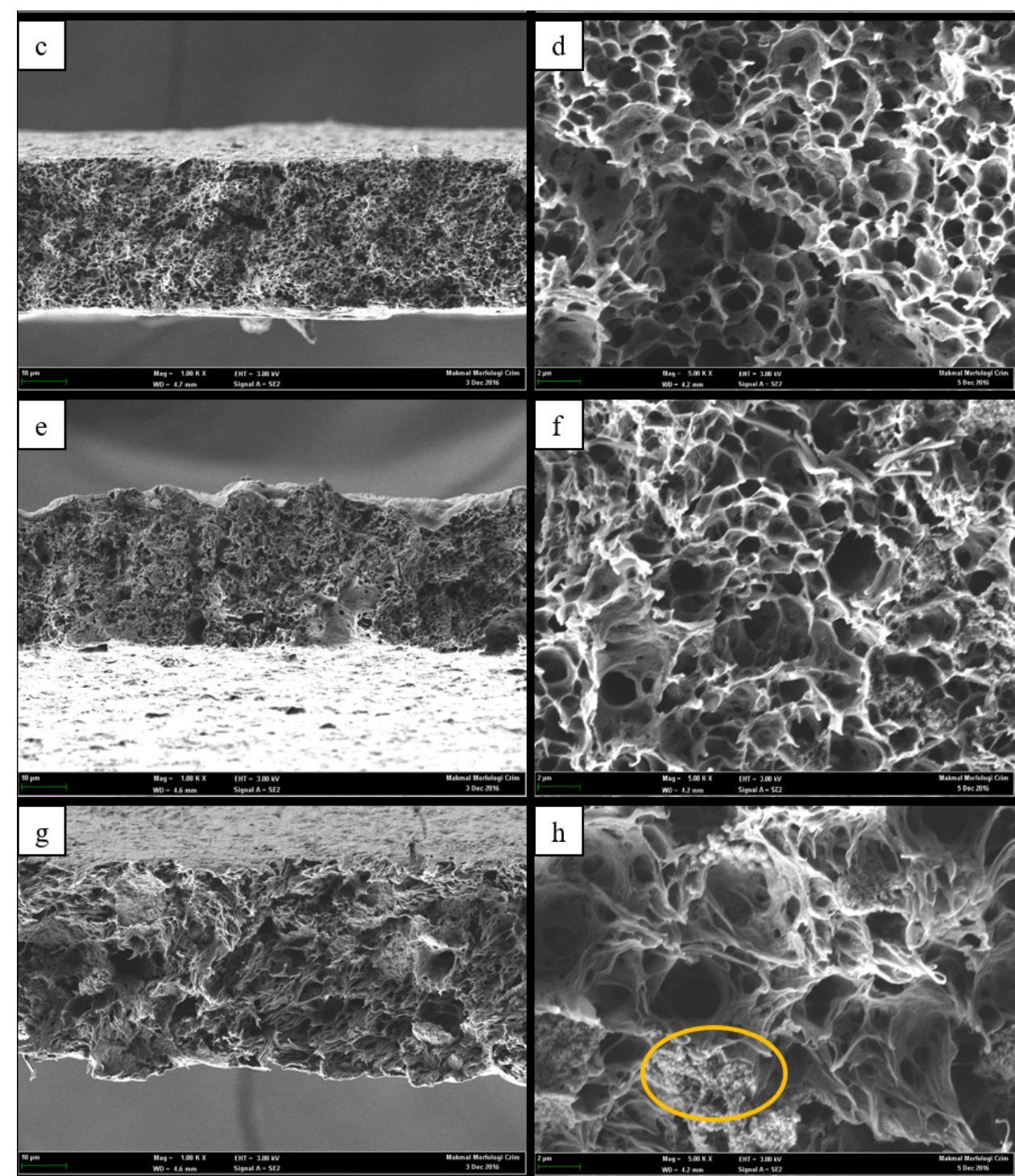

FIGURE 4. Cross sectional surface membranes fabricated with (a,b) $0 \%$, (c,d) $2 \%$, (e,f) $6 \%$ and (g,h) $10 \%$ silica at 1000 (left), and 5000 (right) magnification

The chemical composition of the silicon atom after phase inversion process was determined using the energy dispersive X-ray analysis (EDX) coupled to SEM. This analysis can provide more insight on the formation of large pores in the PLLA-PEG membrane fabricated with $10 \%$ of silica as observed from the SEM micrograph. EDX results are shown in Table 4. Interestingly, lower percentages of silicon were recorded for membrane fabricated with 6 and $10 \%$ of silica in comparison to that of $2 \%$ of silica, with values of $0.74,0.99$ and $1.17 \%$, respectively. The amount of silicon in 6 and $10 \%$ silica membrane was unexpected to be lower than the $2 \%$ silica membrane, since theoretically, the trend should correspond to the increasing amount of concentration of silica added during membrane preparation. This data supports the observation of large pores in membrane fabricated with $10 \%$ of silica due to the agglomeration of silica during mixing followed by the leaching of some silica particles during phase inversion. Membrane fabrication via phase inversion retained a fraction of the silica added where it acted as pore-forming agent in the membrane and leached the rest which acted like a pore template for the membrane. 
Even though there was no agglomeration process happened in the $6 \%$ silica membrane, the amount of silicon in the membrane showed the lowest amount due to high leaching process occurred. This resulted to the increase of pore distribution on the surface of membranes as can be seen in Figure 3(c).

TABLE 4. Silicon composition in PLLA-PEG copolymer membranes

\begin{tabular}{ccccc}
\hline$\%$ of silica added during membrane fabrication & 0 & 2 & 6 & 10 \\
\hline$\%$ of silicon from EDX analysis & 0 & 1.17 & 0.74 & 0.99 \\
\hline
\end{tabular}

\section{WATER CONTACT ANGLE ANALYSIS}

Water contact angle (WCA) analysis was used to determine the hydrophilic/hydrophobic property of membranes with respect to the concentration of silica during membrane preparation. The membrane matrix comprises of 70 weight- $\%$ of PLLA (hydrophobic polymer) and 30 weight-\% of PEG (hydrophilic polymer). Regardless of the greater amount of PLLA present, all of the membranes showed hydrophilic property which PEG as a hydrophilic polymer played an important role in enhancing the hydrophilicity of the membranes (Akbari et al. 2016; Yunos et al. 2014). Nevertheless, the increase in hydrophilicity of membranes were also being achieved due to the amount of silica added. Silica as an inorganic filler can alter the fillerpolymer interfacial interaction by increasing the number of particle-matrix interactions when dispersed in a polymer and ultimately improved the overall material (Chen et al. 2010). The initial WCA of the PLLA-PEG copolymer membrane was $82 \%$ without the presence of hydrophilic silica on the surface of membranes.

Reduction of contact angle values was observed upon the addition of silica, indicating highly hydrophilic character as water molecules have a great affinity and low resistance to wet the surface layer of membranes (Ali Amat et al. 2015). After the addition of $2 \%$ of silica, the WCA of membrane was reduced to $57 \%$ followed by 55 and $49 \%$ for PLLA-PEG copolymer membrane with addition of 6 and $10 \%$, respectively. This phenomenon was occurred due to formation of hydrogen bond between the hydrophilic groups present in silica $(\mathrm{Si}-\mathrm{OH})$ with water (Mohd Nizar et al. 2018). Another factor that could contributed to the decrease of WCA of membrane was the surface morphology of the membrane that could be seen in SEM micrograph. As can be seen in SEM micrograph, membranes with 2,6 , and $10 \%$ of silica presented a better pore distribution and porosity compared to PLLA-PEG copolymer, that helps in lowering the water contact angle. This findings was consistent with the study of Jose et al. (2016) and Zhu et al. (2015) that showed the pores and chemical structures of the surface of membrane can affect its WCA and adhesion behavior.

\section{PERFORMANCE TEST OF MEMBRANE PERMEATION OF POME}

Figure 5 displays the permeation flux of membranes in the treatment of POME with a constant pressure of 3 bar as a function of time. Membrane fabricated with $6 \%$ silica showed the highest value of total mean flux at $42.27 \mathrm{Lhr}^{-1} \mathrm{~m}^{-2}$, followed by $2 \%$ silica at $27.12 \mathrm{Lhr}^{-}$ ${ }^{1} \mathrm{~m}^{-2}$. It was expected that the membrane with better pore

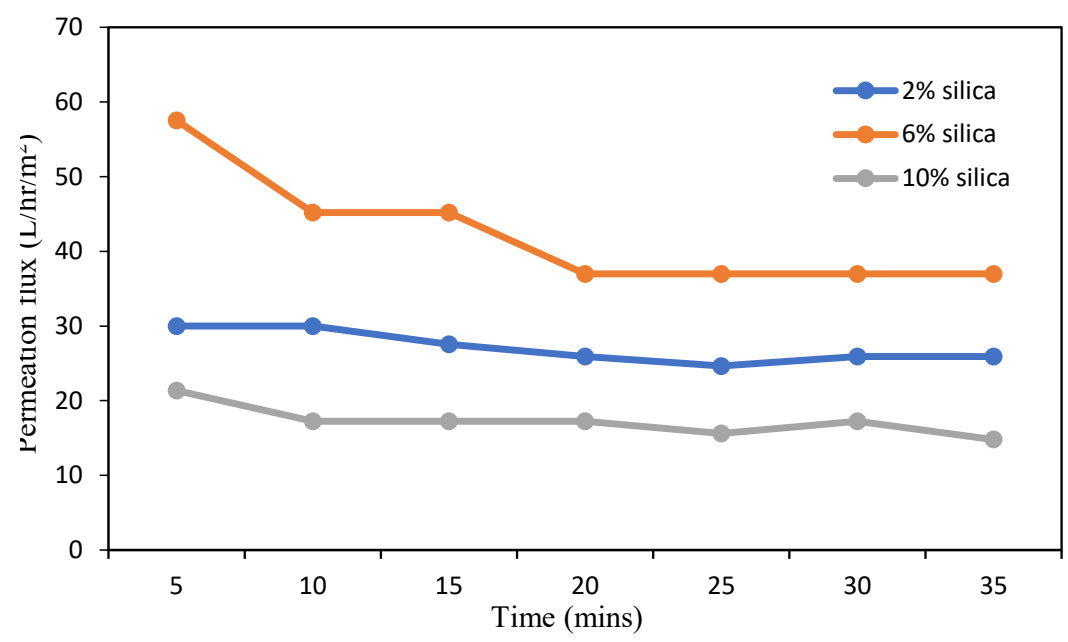

FIGURE 5. Permeation flux of POME for membranes fabricated with 2,6 , and $10 \%$ silica 
distribution presented superior POME flux than a smaller pore membrane. This could be supported by studies of Ahmed et al. (2015) and Sidik et al. (2018) that stated the bigger contribution to enhancing pure water flux and reducing solute rejection were the number of pores on the membrane surface and the better interconnectivity inside the membrane. Meanwhile, membrane fabricated with $10 \%$ silica has the lowest total mean flux at 14.79 $\mathrm{Lhr}^{-1} \mathrm{~m}^{-2}$. Despite having a large pore size, this membrane demonstrated a lowest permeation flux due to the water retention of agglomerated silica present inside the matrix membrane. This agglomeration can undoubtedly seen in the cross-sectional SEM micrographs. In addition, another author also relates that the improved hydrophilicity and water permeability of membranes were attributed by the surface opening pores and highly hydrophilic PEG (Kim \& Lee 1998).

\section{DISCOLORATION OF POME}

The color changes of POME after treatment indicate the color removal efficiency of the PLLA-PEG copolymer membrane influenced by silica. The initial color of
POME before the filtration treatment was dark brown. As shown in Figure 6, filtration treatment using PLLA-PEG copolymer membranes with and without silica significantly improves the color of POME from dark brown to light brown. The trend in color removal efficiency precisely followed the pore size of the membrane. The greater the pore size, the clearer the color of POME. As can be observed in the results, untreated POME appeared to be in dark brown color (Figure 6(a)) while POME treated with membrane fabricated without silica which was PLLAPEG copolymer membrane (Figure 6(b)) and 2\% silica membrane (Figure 6(c)) appeared as a brown solution. Meanwhile, 6\% silica membrane (Figure 6(d)) did show a changed of color that has turn into a lighter brown. Copolymer membrane fabricated with $10 \%$ of silica achieved the highest removal efficiency with the lightest brown and nearly yellow color, but this observation took longer time and higher pressure in order for the color to be achieved. Visual observation showed that the addition of silica gives a better appearance in the discoloration of the treated POME.

QUALITY OF POME

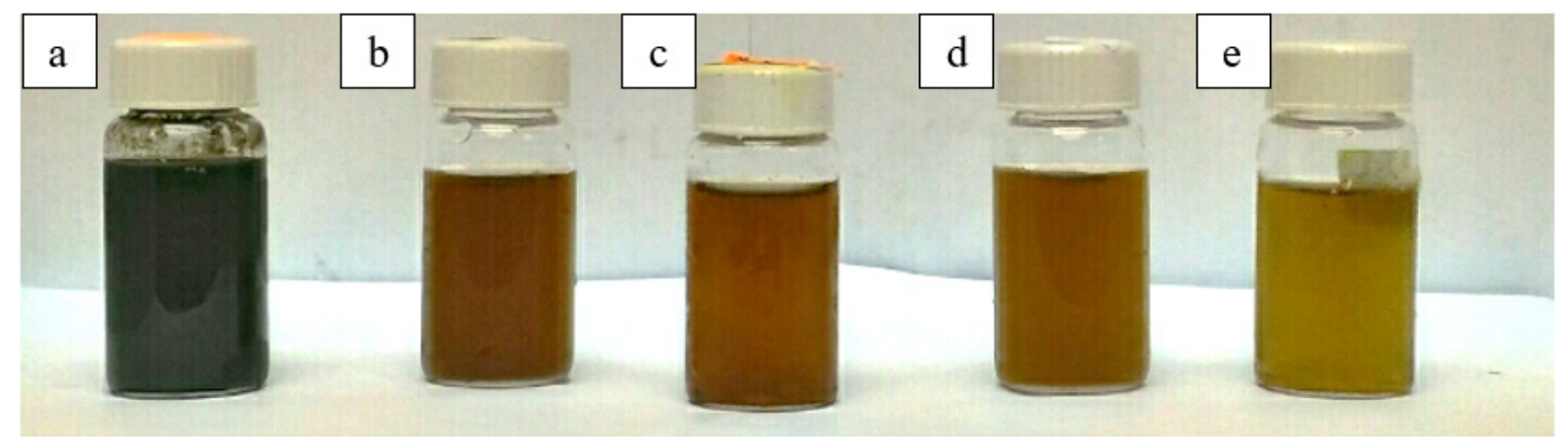

FIGURE 6. Discolouration of POME for (a) untreated

POME, and membranes fabricated with (b) $0 \%$ (PLLA-PEG copolymer) (c) $2 \%$, (d) $6 \%$ and (e) $10 \%$ silica

The critical concern about raw POME was the high concentration of its physicochemical parameters which included biochemical oxygen demand (BOD), chemical oxygen demand (COD), total suspended solids (TSS), and $\mathrm{pH}$. They reflect the high contents of organic material such as a vigorous amount of amino acids and inorganic material like nutrients in the POME. These organic and inorganic materials have an adverse effect on the environment (Xiong et al. 2017). Table 5 summarizes the BOD, COD, TSS, and $\mathrm{pH}$ of POME before and after treatment using PLLA-PEG copolymer membranes with the percentage of removal efficiency. In general, PLLA-PEG copolymer membranes with silica as filler successfully reduced the level of $\mathrm{BOD}, \mathrm{COD}$ and TSS with percentage removal efficiency up to $99.58 \%$. BOD is the measure of oxygen required to oxidize inorganic material and degradation of organic material. Our finding showed that $2 \%$ and $6 \%$ silica membranes plays a significant role in reducing the amount of BOD in treated POME that gave the almost similar value of removal efficiencies which were 98.3 and $98.1 \%$, respectively. Apart from it, the performance of COD after the treatment disclosed a 
similar trend to the performance of BOD. The major reduction of $\mathrm{BOD}$ and $\mathrm{COD}$ values suggested a decrease in organic and inorganic material present after the treatment. These values of BOD and COD were relatable to the removal efficiency of total suspended solid (TSS). A well distributed and high porosity of pores in the PLLA-PEG/ silica membranes was effective in trapping the suspended solid onto the membrane and allowing only clean water to pass through the membranes. Likewise, the successful separation of organic and inorganic material lead to major removal efficiencies of BOD, COD, and TSS in treated POME. As for the $\mathrm{pH}$, the $\mathrm{pH}$ of POME remains unchanged throughout the treatment. These final readings enabled the treated POME to achieve DOE standards within the discharge limit. Furthermore, this membrane system showed unique characteristic as many studies found that membrane technology is effective in reducing the concentrated color of POME (Adeleke et al. 2017).

TABLE 5. BOD, COD, TSS, and $\mathrm{pH}$ of POME before and after treatment with PLLA-PEG copolymer membranes

\begin{tabular}{|c|c|c|c|c|c|c|c|}
\hline \multirow{3}{*}{$\begin{array}{l}\text { Percentage of } \\
\text { silica }\end{array}$} & \multicolumn{2}{|c|}{ BOD } & \multicolumn{2}{|c|}{ COD } & \multicolumn{2}{|c|}{ TSS } & \multirow{2}{*}{$\begin{array}{c}\mathrm{pH} \\
\text { Initial }=8.39\end{array}$} \\
\hline & \multicolumn{2}{|c|}{ Initial $=12300$} & \multicolumn{2}{|c|}{ Initial $=40820$} & \multicolumn{2}{|c|}{ Initial $=38693$} & \\
\hline & Final & $\begin{array}{l}\text { Removal } \\
\text { efficiency }\end{array}$ & Final & $\begin{array}{l}\text { Removal } \\
\text { efficiency }\end{array}$ & Final & $\begin{array}{l}\text { Removal } \\
\text { efficiency }\end{array}$ & Final \\
\hline $0 \%$ & 350 & $97.2 \%$ & 1468 & $96.5 \%$ & 200 & $99.48 \%$ & 8.62 \\
\hline $2 \%$ & 210 & $98.3 \%$ & 1443 & $96.4 \%$ & 190 & $99.58 \%$ & 8.72 \\
\hline $6 \%$ & 230 & $98.1 \%$ & 1283 & $96.9 \%$ & 250 & $99.50 \%$ & 8.54 \\
\hline $10 \%$ & 380 & $96.9 \%$ & 1898 & $95.4 \%$ & 160 & 99.355 & 8.65 \\
\hline
\end{tabular}

\section{CONCLUSION}

The important conclusion drawn from this work include membrane fabrication via phase inversion retained a fraction of the silica added where it acted as poreforming agent in the membrane and leached the rest which acted like a pore-template for the membrane. The presence of urethane and silica peaks in FTIR analysis was suggested the successful functionalization of PLLAPEG copolymer membrane consist of silica. Moreover, SEM-EDX analysis shown that the porosity and amount of silica retained in the membrane clearly affected by the percentage of silica added. Unfortunately, a $10 \%$ silica membrane did show unexpected behavior as the silica had agglomerated and left a non-uniform size of pores, while $6 \%$ silica membrane seemed evident to be the most suitable candidate that could be implemented in managing POME wastewater. As for the application of POME treatment, PLLA-PEG copolymer membrane with addition of silica did show a significant reduction in discoloration test and quality test such as BOD, COD, and TSS.

\section{ACKNOWLEDGEMENTS}

The authors would like to thank Universiti Kebangsaan Malaysia (UKM) for providing analytical equipment used in this research. This work was supported by the Ministry of Education, Malaysia and Universiti Kebangsaan Malaysia under research grants FRGS/1/2019/STG01/ UKM/02/8 and GUP-2016-060.

\section{REFERENCES}

Adeleke, A.O., Latiff, A.A.A., Al-Gheethi, A.A. \& Daud, Z. 2017. Optimization of operating parameters of novel composite adsorbent for organic pollutants removal from POME using response surface methodology. Chemosphere 174: 232-242.

Ahmed, Y., Yaakob, Z., Akhtar, P. \& Sopian, K. 2015. Production of biogas and performance evaluation of existing treatment processes in palm oil mill effluent (POME). Renewable and Sustainable Energy Reviews 42: 1260-1278.

Akbari, A., Yegani, R., Pourabbas, B. \& Behboudi, A. 2016. Fabrication and study of fouling characteristics of HDPE/ PEG grafted silica nanoparticles composite membrane for filtration of Humic acid. Chemical Engineering Research and Design 109: 282-296. 
Ali Amat, N.A., Tan, Y.H., Lau, W.J., Lai, G.S., Ong, C.S., Mokhtar, N.M., Sani, N.A.A., Ismail, A.F., Goh, P.S., Chong, K.C. \& Lai, S.O. 2015. Tackling colour issue of anaerobically-treated palm oil mill effluent using membrane technology. Journal of Water Process Engineering 8: 221226.

Ang, H.Y., Toong, D., Chow, W.S., Seisilya, W., Wu, W., Wong, P., Venkatraman, S.S., Foin, N. \& Huang, Y. 2018. Radiopaque fully degradable nanocomposites for coronary stents. Scientific Reports 8(1): 17409.

Basu, T., Pal, B. \& Singh, S. 2018. Fabrication of core-shell PLGA/PLA-pNIPAM nanocomposites for improved entrapment and release kinetics of antihypertensive drugs. Particuology 40: 169-176.

Chen, J., Spear, S.K., Huddleston, J.G. \& Rogers, R.D. 2005. Polyethylene glycol and solutions of polyethylene glycol as green reaction media. Green Chemistry 7: 64-82.

Chen, W., Su, Y., Zhang, L., Shi, Q., Peng, J. \& Jiang, Z. 2010. In situ generated silica nanoparticles as pore-forming agent for enhanced permeability of cellulose acetate membranes. Journal of Membrane Science 348(1-2): 75-83.

Chieng, B.W., Ibrahim, N.A., Yunus, W.M.Z.W. \& Hussein, M.Z. 2014. Poly(lactic acid)/poly(ethylene glycol) polymer nanocomposites: Effects of graphene nanoplatelets. Polymers 6(1): 93-104.

El-Gendy, A., Abou-zeid, R.E., Salama, A., Diab, M.A. \& ElSakhawy, M. 2017. TEMPO-oxidized cellulose nanofibers/ polylactic acid/ $\mathrm{TiO}_{2}$ as antibacterial bionanocomposite for active packaging. Egyptian Journal of Chemistry 60(6): 1007-1014.

Feifel, S.C. \& Lisdat, F. 2011. Silica nanoparticles for the layerby-layer assembly of fully electro-active cyctochrome $c$ multilayers. Journal of Nanobiotechnology 9(59): 1-12.

Feng, P., Peng, S., Wu, P., Gao, C., Huang, W., Deng, Y. \& Shuai, C. 2016. A space network structure constructed by tetraneedlelike $\mathrm{ZnO}$ whiskers supporting boron nitride nanosheets to enhance comprehensive properties of poly(Llacti acid) scaffolds. Scientific Reports 6: 33385.

Gaitán, A. \& Gacitúa, W. 2018. Morphological and mechanical characterization of electrospun polylactic acid and microcrystalline cellulose. BioResources 13(2): 3659-3673.

Ghani, M.S.H., Haan, T.Y., Lun, A.W., Mohammad, A.W., Ngteni, R. \& Yusof, K.M.M. 2018. Fouling assessment of tertiary palm oil mill effluent (POME) membrane treatment for water reclamation. Journal of Water Reuse and Desalination 8(3): 412-423.

Gui, Z., Xu, Y., Gao, Y., Lu, C. \& Cheng, S. 2012. Novel polyethylene glycol-based polyester toughened polylactide. Materials Letters 71: 63-65.

Jose, J.P., Abraham, J., Maria, H.J., Varughese, K.T. \& Thomas, S. 2016. Contact angle studies in XLPE hybrid nanocomposites with inorganic nanofillers. Macromolecular Symposia 366(1): 66-78.

Kim, J.H. \& Lee, K.H. 1998. Effect of PEG additive on membrane formation by phase inversion. Journal of Membrane Science 138(2): 153-163.

Liu, H-C., Lee, I-C., Wang, J-H., Yang S-H., \& Young, T-H. 2004. Preparation of PLLA membranes with different morphologies for culture of MG-63 cells. Biomaterials 25(18): 4047-4056.
Mahatmanti, F.W., Nuryono, N. \& Siswanta, D. 2018. Preparation and characterization of composite membrane chitosan-silicapolyethylene glycol. Defect and Diffusion Forum 382: 3-6.

Mohd Nizar, M., Hamzah, M.S.A., Abd Razak, S.I. \& Mat Nayan, N.H. 2018. Thermal stability and surface wettability studies of polylactic acid/halloysite nanotube nanocomposite scaffold for tissue engineering studies. IOP Conference Series: Materials Science and Engineering 318: 012006.

Nagarajan, V., Mohanty, A.K. \& Misra, M. 2016. Perspective on polylactic acid (PLA) based sustainable materials for durable applications: Focus on toughness and heat resistance. ACS Sustainable Chemisty and Engineering 4(6): 28992916.

Nasrin, R., Biswas, S., Rashid, T.U., Afrin, S., Jahan, R.A., Haque, P. \& Rahman, M.M. 2017. Preparation of chitin-PLA laminated composite for implantable application. Bioactive Materials 2(4): 199-207.

Norfarhana, A.S. 2014. Penyediaan adunan getah asli terepoksida/poli(vinil klorida)/sekam padi (ENR/PVC/ SP) sebagai membran bagi rawatan air buangan. School of Chemical Sciences and Food Technology, Faculty of Science and Technology, Universiti Kebangsaan Malaysia, Ph.D. Thesis (Unpublished).

Phaechamud, T. \& Chitrattha, S. 2016. Pore formation mechanism of porous poly(DL-lactic acid) matrix membrane. Materials Science and Engineering: C 61: 744-752.

Ruf, M.F.H.M., Ahmad, S., Chen, R.S., Shahdan, D. \& Zailan, F.D. 2018. Tensile and morphology properties of PLA/LNR blends modified with maleic anhydride grafted-polylactic acid and-natural rubber. AIP Conference Proceeding 1940(1): 020015.

Saljoughi, E., Amirilargani, M. \& Mohammadi, T. 2010. Effect of PEG additive and coagulation bath temperature on the morphology, permeability and thermal/chemical stability of asymmetric CA membranes. Desalination 262: 72-78.

Sidik, A.M., Othaman, R. \& Anuar, F.H. 2018. The effect of molecular weight on the surface and permeation of poly $(\mathrm{L}$ lactic acid)-poly(ethylene glycol) membrane with activated carbon filler. Sains Malaysiana 47(6): 1181-1187.

Wang, Z., Pan, Z., Wang, J. \& Zhao, R. 2016. A novel hierarchical structured poly(lactic acid)/titania fibrous membrane with excellent antibacterial and air filtration performance. Journal of Nanomaterials 2016: 1-17.

Xian, X., Wang, X., Zhu, Y., Guo, Y. \& Tian, Y. 2018. Effects of MCC content on the structure and performance of PLA/MCC biocomposites. Journal of Polymers and the Environment 26: 3484-3492.

Xiong, Z., Zhong, Y., Lin, H., Liu, F., Li, T. \& Li, J. 2017. PDLA/PLLA ultrafiltration membrane with excellent permeability, rejection and fouling resistance via stereocomplexation. Journal of Membrane Science 533: 103-111.

Yunos, M.Z., Harun, Z., Basri, H. \& Ismail, A.F. 2014. Studies on fouling by natural organic matter (NOM) on polysulfone membranes: Effect of polyethylene glycol (PEG). Desalination 333(1): 36-44.

Zainal, N.H., Jalani, N.F., Mamat, R. \& Astimar, A.A. 2017. A review on the development of palm oil mill effluent (POME) 
final discharge polishing treatments. Journal of Oil Palm Research 29(4): 528-540.

Zainuddin, A.A., Othaman, R., Aqma, W.S., Akiyoshi, T., Shinya, T. \& Anuar, F.H. 2018. Synthesis and thermal properties of poly(ethylene glycol)-polydimetylsiloxane crosslinked copolymers. Sains Malaysiana 47(6): 1117-1122.

Zhu, L., Liu, F., Yu, X. \& Xue, L. 2015. Poly(lactic acid) hemodialysis membranes with poly(lactic acid)-blockpoly(2-hydroxyethyl methacrylate) copolymer as additive: Preparation, characterization, and performance. ACS Applied Material Interfaces 7(32): 17748-17755.

Fatimah Zahrah Mohd Kamil, Norilyani Izzati Hasanuddin, Rizafizah Othaman \& Farah Hannan Anuar*

Department of Chemical Sciences

Faculty of Science and Technology

Universiti Kebangsaan Malaysia

43600 UKM Bangi, Selangor Darul Ehsan

Malaysia
Rizafizah Othaman \& Farah Hannan Anuar* Polymer Research Centre (PORCE)

Faculty of Science and Technology

Universiti Kebangsaan Malaysia 43600 UKM Bangi, Selangor Darul Ehsan Malaysia

*Corresponding author; email: farahhannan@ukm.edu.my

Received: 15 October 2019

Accepted: 8 May 2020 